\title{
Effect of gibberellin and retardants on the germination of seeds with different types of reserve substances under the conditions of skoto- and photomorphogenesis
}

Iryna Poprotska ${ }^{1^{*}}$,

Volodymyr Kuryata ${ }^{1}$,

Olena Khodanitska ${ }^{1}$,

Stepan Polyvanyi ${ }^{1}$,

Lyudmyla Golunova ${ }^{1}$,

Yuriy Prysedsky²

${ }^{1}$ Vinnytsia Mykhailo Kotsiubynsky

State Pedagogical University,

Ostroz'kogo St., 32,

Vinnytsia 21000, Ukraine

${ }^{2}$ Vasyl Stus Donetsk

National University,

600-richya St., 21,

Vinnytsia 21021, Ukraine
The influence of preparations of phytohormone gibberellin and antigibberellin-retardants tebuconazole and chlormequat chloride - on the germination of plant seeds with different types of reserve compounds in the light (photomorphogenesis) and in the dark (skotomorphogenesis) was studied. It was established that under the action of gibberellin, stimulation of the aboveground part and root system growth of maize, beans and pumpkin seedlings was more intensive in comparison with the control. This process was faster in the dark. The use of tebuconazole and chlormequat chloride significantly inhibited the process of germination both in the light and in the dark. At the same time, the coefficient of the use of reserve substances was maximal under the action of gibberellin, and minimum under the action of retardants, both under the conditions of skoto- and photomorphogenesis. The change in the growth characteristics and the coefficient of the use of reserve substances of bean seeds was accompanied by a decrease in the content of total nitrogen, indicating the use of reserve nitrogen-containing compounds in the processes of morphogenesis. The content of protein nitrogen in the control was lower under the conditions of skotomorphogenesis than in the photomorphic seedlings, and the opposite effect was noted for the actions of gibberellin and the retardant. In the later stages of germination, the largest reserve oil of pumpkin seed remained in cotyledonary leaves of photomorphic plants under the effects of chlormequat chloride, which clearly correlated with the least intense growth rates of seedlings in this variant, both in the light and darkness. Under conditions of skotomorphogenesis the growth stimulating effect of gibberellin significantly increased, and the light blocked the action of this phytohormone.

Keywords: effect of light, morphogenesis, source-sink system, seed germination, gibberellins, retardants

*Corresponding author. Email: i_poprotska@ukr.net 


\section{INTRODUCTION}

The problem of artificial redistribution of assimilates and nutrition elements between plant organs is one of the central in modern phytophysiology since its solution will allow to effectively regulate the activity of physiological functions of the plant and purposefully redistribute the flows of assimilates to economically valuable organs (Bonelli et al., 2016; Kuryata et al., 2017; Kuryata, Golunova, 2018). Research into the source-sink system of plants is mainly carried out on growth processes and photosynthesis. Photosynthesis is considered as a donor (source) of assimilates and growth processes as an acceptor (sink) (Yu et al., 2015; Kuryata, Polyvanyj, 2018; Kuryata, Khodanitska, 2018). These relationships in plants are regulated at different levels (Matysiak, Kaczmarek, 2013; Savage et al., 2015; Sugiura et al., 2015; Humplík et al., 2015). At the same time, there is much less information about the functioning of this system during the period of germination of bulbs, tubers, and rhizomes in the heterotrophic phase of development (Kuryata et al., 2017). During this period, reserve compounds of various chemical structures - carbohydrates, nitrogen-containing compounds, oils etc., which are deposited in the reserve organs - are used for the needs of morphogenesis.

The development of plants in the light and in the dark during the period of germination is characterized by differences in the intensity of use of reserve substances deposited in the reserve organs, resulting in a change in the degree of tension between the source and the sink activity. Some works provide data that indicate the possibility of regulating the rate of utilization of reserve compounds for the needs of growth and development by external and internal factors (Altintas, 2011; Kutschera, Briggs, 2013; Kuryata, Kravets, 2018).

It is established that light not only provides the process of carbon feeding and determines the transition to reproductive development; it also starts a photoromogenesis programme through the system of photoreceptors (phytochromes, cryptochromes and phototropin)
(Hornitschek et al., 2012; Wu, 2014; Franklin, 2016). This ensures the differentiation of chloroplasts, the formation of full-fledged leaves and the transition to the phase of autotrophic nutrition. Plants that grow in complete darkness develop in accordance with the scotomorphogenesis programme: there is an extension of epicotyl and hypocotyl, the formation of hypocotyl loops, yellowing of cotyledons, and corrugated first leaves. In monocotyledonous and dicotyledonous plants, there is a significant difference in the morphology of seedlings grown in the light and in the dark. In monocotyledonous seedlings (oats, maize) during etiolation there is a stretching in the length of the axial organs and the leaf. At the same time, in dicotyledonous plants, only interstitials of the stem (hypocotyl, epicotyl) are stretched, and the primary leaves and cotyledons do not change much.

Among the internal factors of tension regulation of donor-acceptor relationships, the hormonal system plays the key role. Today, it has been established that light can modify the growth and morphogenesis of plants through the restructuring of the hormonal complex (Kutschera, Briggs, 2013; Wu, 2014; De Wit, Pierik, 2016). In particular, it is known that the meristem activity is controlled by phytohormones gibberellins (Hedden, Thomas, 2016). The gene of biosynthesis AtGA3ox1 positively affects the activity of phytochrome, increasing the level of bioactive gibberellins during germination of Arabidopsis seeds.

It was established that red light blocks the formation of GA 2-oxidases, which leads to a significant increase in the content of gibberellins in the seeds of lettuce during germination under the effect of red light (Nakaminami et al., 2003). The blue light suppressed the hypocotyl stretching of the etiolated Arabidopsis seedlings by means of mechanisms dependent on photoreceptor phytochrome, in particular by encoding the enzymes of biosynthesis of gibberellins and enzymes associated with cell wall metabolism (Folta et al., 2003).

It was established that one of the most important functions of gibberellins in stimulating the seed germination process in cereals is 
the ability to stimulate the secretion of the embryo in the endosperm of $\alpha$-amylase leading to the splitting of starch grains (Rademacher, 2016). At the same time, it should be noted that there are little-studied features of gibberellin regulation of germination of seeds and vegetative organs of plants containing as a reserve substance proteins, lipids, inulin and other compounds, but not starch. Synthetic substances retardants that have an antigibberellin mechanism of action are widely used to block the physiological action of gibberellins (Carvalho, 2016; Koutroubas, Damalas, 2016; Yan et al., 2015; Wang et al., 2016). Retardants either inhibit the synthesis of gibberellins or the activity of already synthesized gibberellin (Kuryata, 2009; Sang-Kuk, Hak-Yoon, 2014; Yang et al., 2016).

At the same time, although retardants lead to significant changes in the ontogenesis of plants, features of their effects on the development of plants under skoto- and photomorphogenesis remain little known (Ramburan, Greenfield, 2007; Matysiak, Kaczmarek, 2013; Wang et al., 2016).

In this regard, the purpose of this work was to determine the influence of gibberellin and retardants on the functioning of the "depot assimilates - growth" system during the period of seed germination with different types of reserve compounds under photo- and skotomorphogenesis conditions.

\section{MATERIALS AND METHODS}

The work was carried out with seeds of maize hybrid Dostatok $300 \mathrm{MV}$, originator the Institute of Plant Physiology and Genetics of the National Academy of Sciences of Ukraine (Kyiv); bean seed variety Galaxy, originator the Podillya Institute of Forage and Agriculture, NAAS of Ukraine (Vinnytsya); pumpkin seed variety Mozoliivsky 15, originator Institute of Vegetable and Melons, NAAS of Ukraine (Kharkiv).

The following preparations were used in the work:

(1) gibberellic acid - a white crystalline substance with a molecular weight of 346 .
$2 \mathrm{D}$ with the molecular formula $\mathrm{C}_{19} \mathrm{H}_{22} \mathrm{O}_{6}$. The melting temperature is $227^{\circ} \mathrm{C}$. The substance is poorly soluble in water and well soluble in organic solvents. Gibberellic acid is a low-toxic compound and belongs to grade 3 toxicity. LD50 for rats is $15630 \mathrm{mg} / \mathrm{kg}$. It does not show carcinogenic, blastomogeneous, skin-resorbing and embryotoxic properties. The residual content of the preparation is not normalized, since in plants it is present as a natural metabolite. The preparation is nontoxic to bees and other insects, low toxic for fish (Rademacher, 2016).

(2) folicur and chlormequat chloride preparations were used as retardants. The active substance of the commercial preparation follicur is tebuconazole $\left(\mathrm{C}_{16} \mathrm{H}_{22} \mathrm{ClN}_{3} \mathrm{O}\right)$ - (RS)-1-chlorophenyl-4,4-dimethyl-3- (1H-1,2,4-triazol-1-ylmethyl) pentan-3-yl. Tebuconazole is a colourless substance, well soluble in organic solvents and poorly in water. Molecular weight $308.7 \mathrm{D}$, melting point $104,7^{\circ} \mathrm{C}, \mathrm{LD} 50$ for white rats is $1700 \mathrm{mg} / \mathrm{kg}$, the preparation is low-toxic.

(3) chlormequat chloride ( $\alpha$-chloroethyltrimethylammonium chloride)-[Cl- $\mathrm{CH}_{2}-\mathrm{CH}_{2} \mathrm{~N}$ $\left.\left(\mathrm{CH}_{3}\right)_{3}\right]^{+} \mathrm{Cl}^{-}$. This is a white crystalline substance decomposed at a temperature of $245^{\circ} \mathrm{C}$, insoluble in hydrocarbons, but soluble in water: solubility is $74 \%$ at $20^{\circ} \mathrm{C}$. LD50 for white rats is $640 \mathrm{mg} / \mathrm{kg}$, the maximum daily dose for a human is $0.07-0.09 \mathrm{mg}$. The preparation is low toxic; the maximum level in food is 0.1$0.3 \mathrm{mg} / \mathrm{kg}$ (Kuryata, 2009).

The seeds were soaked in experimental variants in an aqueous solution of gibberellic acid $(150 \mathrm{mg} / \mathrm{l})$, and in solutions of retardants: maize in a solution of $0.06 \%$ tebuconazole, beans in $0.12 \%$ solution of tebuconazole, pumpkin in $0.25 \%$ solution of chlormequat chloride per day, and then planted in moist sand. The control variant was soaked in distilled water. The seeds were sprouted in the dark and in the light at $20^{\circ} \mathrm{C}$. On the 12 th day of germination, a coefficient of using the reserve substances of the seed was established as the ratio of the total dry mass of the seedlings to the mass of the dry matter of the whole plant. The content of sugars 
and starch in cotyledons was determined by the iodometric method, fats by the extraction method in the Soxhlet apparatus with petroleum ether, phosphorus content by the formation of a phosphoric-molybdenum complex, potassium by the flame-photometric method, and total nitrogen by the Kjeldahl method (AOAC, 2010). The analytical repetition of studies is fivefold. The quantitative content and the qualitative composition of higher fatty acids (HFAs) were determined by gas chromatography. Determination of fatty acids contents in soy oil (quantitative components) was indicated by gas chromatography method on chromatograph Crystal-2000 (AOAC, 2010). The conditions of chromatography were the following: glass cylinders $1500 \times 2 \mathrm{~mm}$ filled in with sorbent (fraction $0.16-0.20 \mathrm{~mm}$ ) intertop-super $+5 \%$ neoplex 400 were used. The gas-bearer was nitrogen; its passing rate equalled $70 \mathrm{ml} / \mathrm{min}$. The temperature of the heating oven was $2000^{\circ} \mathrm{C}$, of the evaporator $2300^{\circ} \mathrm{C}$, and of the flame ionizing detector $2400^{\circ} \mathrm{C}$. The analytical recurrence of studies was fivefold.
The results of the research were statistically processed using the software package Statistica 6.0. The tables and figures show the average arithmetic mean and their standard errors.

\section{RESULTS AND DISCUSSION}

The obtained results indicate that the process of germination of maize seeds in the light and in the dark was accompanied by significant changes in plant development due to the action of gibberellin and retardant tebuconazole in conditions of photo- and skotomorphogenesis. The action of gibberellin indicated more intensive stimulation of growth of the aboveground part and root system seedlings than in the control, and the process was more intensive in the dark. The use of antigibberellin preparation tebuconazole significantly inhibited the process of germination both in the light and in the dark (Table 1). Morphological changes of seedlings in the experiment variants were determined by varying degrees of use of reserve substances of seed in the germination period: the rate of use of spare substances

Table 1. Influence of gibberellin and tebuconazole on germination rates of maize seed, hybrid Dostatok $300 \mathrm{MV}$, under the conditions of photo- and skotomorphogenesis

\begin{tabular}{|c|c|c|c|c|c|c|}
\hline \multirow{2}{*}{ Indicator } & \multicolumn{2}{|c|}{ Control } & \multicolumn{2}{|c|}{ Gibberellin } & \multicolumn{2}{|c|}{ Tebuconazole } \\
\hline & Light & Dark & Light & Dark & Light & Dark \\
\hline $\begin{array}{l}\text { The length of above- } \\
\text { ground part, cm }\end{array}$ & $3.0 \pm 0.05$ & $6.0 \pm 0.18^{\star}$ & $4.0 \pm 0.11$ & $15.1 \pm 0.34$ & $1.0 \pm 0.04$ & $1.4 \pm 0.07^{\star}$ \\
\hline $\begin{array}{c}\text { The length of root } \\
\text { system, cm }\end{array}$ & $5.1 \pm 0.15$ & $7.9 \pm 0.18^{\star}$ & $4.8 \pm 0.14$ & $12.1 \pm 0.21$ & $1.8 \pm 0.05$ & $4.3 \pm 0.12^{\star}$ \\
\hline $\begin{array}{l}\text { Coefficient of use of } \\
\text { reserve substances, \% }\end{array}$ & $12.0 \pm 0.50$ & $20.0 \pm 0.90^{*}$ & $14.0 \pm 0.40$ & $25.0 \pm 0.80^{*}$ & $6.0 \pm 0.30$ & $7.0 \pm 0.20^{*}$ \\
\hline $\begin{array}{l}\text { Starch content, \% } \\
\text { mass of dry matter }\end{array}$ & $9.2 \pm 0.02$ & $55.1 \pm 0.03$ & $52.0 \pm 0.02$ & $49.0 \pm 0.04$ & $8.1 \pm 0.05$ & $58.1 \pm 0.05$ \\
\hline $\begin{array}{l}\text { Total nitrogen con- } \\
\text { tent, } \% \text { mass of dry } \\
\text { matter }\end{array}$ & $1.4 \pm 0.02$ & $1.3 \pm 0.01^{\star}$ & $1.2 \pm 0.03$ & $1.7 \pm 0.02^{\star}$ & $1.4 \pm 0.03$ & $1.4 \pm 0.02^{*}$ \\
\hline $\begin{array}{l}\text { Phosphorus content, } \\
\text { g/kg of dry matter }\end{array}$ & $3.8 \pm 0.01$ & $3.3 \pm 0.01^{\star}$ & $3.6 \pm 0.04$ & $4.0 \pm 0.04^{\star}$ & $3.5 \pm 0.05$ & $3.7 \pm 0.02^{\star}$ \\
\hline $\begin{array}{l}\text { Potassium content, } \\
\text { g/kg of dry matter }\end{array}$ & $1.6 \pm 0.04$ & $1.2 \pm 0.01^{\star}$ & $1.5 \pm 0.02$ & $1.9 \pm 0.03^{\star}$ & $1.5 \pm 0.01$ & $1.6 \pm 0.03$ \\
\hline
\end{tabular}

Note: ${ }^{*}$ - the difference is significant at $P \leq 0.05$. 
under the action of tebuconazole was minimal in both light and in the dark. The stimulating effect of gibberellin on germination under skotomorphogenesis was characterized by a higher value of this indicator. As under the influence of gibberellin, the growth and morphogenesis of seedlings increased in comparison with the action of the retardant, it is important to analyse the outflow of the reserve substance from the seed to the acceptor zone (seedlings) according to the experimental variants due to the formation of a different request for reserve metabolites.

The main reserve substance of maize seeds is starch. The analysis of the obtained results shows that the higher value of the coefficient of the use of reserve substances in the dark and under the action of gibberellin is determined by more intensive hydrolysis of the reserve polysaccharide: its content in these variants significantly decreased. Germination of a seed in which the main reserve substance is starch is accompanied by the synthesis de novo and the release by the embryo into the endosperm amylase under the action of gibberellin, which leads to the splitting of starch grains (Rademacher, 2016). Processing by exogenous gibberellin also enhances these processes and stimulates the growth of the sprout. The use of retardants, which are gibberellin antagonists, reduces the demand for asymilates due to the blockage of gibberellin synthesis, the activity of the amylase complex, and the decrease in the activity of the meristem. As a result, tebuconazole has a minimal effect on the changes in the content of starch in sprouted maize seeds, both in the light and in the dark. This is in good agreement with the lowest values of the use of reserve substances and the lowest growth rate of seedlings in these variants (Table 1).

The literature does not contain data on the redistribution of elements of mineral nutrition between seed and seedlings during germination under the action of gibberellin and retardants in the light and in the dark. Analysis of the content of total nitrogen in the seed of sprouted seeds indicates that under the condi- tions of photo- and skotomorphogenesis the differences were minimal.

At the same time, the use of gibberellin and retardant contributed to the increase in nitrogen content in the dark, contrary to the variant with light. In our opinion, this is clearly explained by the peculiarities of biodegradation: more efficient use of the main reserve substance, starch, led to an increase in the relative content of nitrogen. This also indicates that starch is primarily used, and protein compounds are used at later stages of germination. A similar trend was observed for the use of reserve forms of phosphorus and potassium: in the control version, utilization of mineral elements of seeds was more intensive in the dark, and in experimental variants the content of phosphorus was higher in the dark. Consequently, under the conditions of scotomorphogenesis, the growth-stimulating effect of gibberellin significantly increased. Antigibberellin action of tebuconazole resulted in significant inhibition of germination and the use of reserve compounds of maize seeds, both in the light and in the dark. This indicates the key role of gibberellin in seed germination processes that contain starch as a reserve substance.

In the analysis of the effect of gibberellin and retardant tebuconazole on the growth of bean seedlings under conditions of photoand skotomorphogenesis, it was established that gibberellin less stimulated the growth of these seedlings compared to maize sprouts (Table 2).

In beans, a significant part of the reserve substances of cotyledons is nitrogen-containing compounds. The change in the growth characteristics and the coefficient of use of seed reserve materials was accompanied by a decrease in the content of total nitrogen, indicating the use of reserve nitrogen-containing compounds in the processes of morphogenesis. In this case, under the conditions of skotomorphogenesis, the content of protein nitrogen in the control was lower than in the photomorphic seedlings, and the opposite effect was noted in the actions of gibberellin and retardant. 
Table 2. Influence of gibberellin and tebuconazole on the germination rates of bean seeds, variety Galaxy, under the conditions photo- and skotomorphogenesis

\begin{tabular}{|c|c|c|c|c|c|c|}
\hline \multirow{2}{*}{ Indicator } & \multicolumn{2}{|c|}{ Control } & \multicolumn{2}{|c|}{ Gibberellin } & \multicolumn{2}{|c|}{ Tebuconazole } \\
\hline & Light & Dark & Light & Dark & Light & Dark \\
\hline $\begin{array}{l}\text { Length of seedlings, } \\
\mathrm{cm}\end{array}$ & $9.4 \pm 0.50$ & $10.0 \pm 0.50$ & $9.3 \pm 0.46$ & $12.6 \pm 0.50^{*}$ & $6.3 \pm 0.31$ & $9.4 \pm 0.47^{\star}$ \\
\hline $\begin{array}{l}\text { Coefficient of use of } \\
\text { reserve substances, \% }\end{array}$ & $21.0 \pm 0.50$ & $28.0 \pm 0.30^{*}$ & $25.0 \pm 0.50$ & $37.0 \pm 0.30^{*}$ & $15.0 \pm 0.30$ & $16.0 \pm 0.40^{*}$ \\
\hline $\begin{array}{c}\text { Total nitrogen con- } \\
\text { tent, } \% \text { mass of dry } \\
\text { matter }\end{array}$ & $4.57 \pm 0.04$ & $4.15 \pm 0.02^{\star}$ & $4.14 \pm 0.02$ & $4.08 \pm 0.02^{*}$ & $4.17 \pm 0.03$ & $4.07 \pm 0.01^{\star}$ \\
\hline $\begin{array}{c}\text { Protein nitrogen } \\
\text { content, \% mass of } \\
\text { dry matter } \\
\end{array}$ & $3.21 \pm 0.03$ & $3.12 \pm 0.02^{*}$ & $2.95 \pm 0.02$ & $3.07 \pm 0.03^{\star}$ & $3.04 \pm 0.02$ & $3.18 \pm 0.01^{\star}$ \\
\hline $\begin{array}{l}\text { Non-protein nitro- } \\
\text { gen content, \% by } \\
\text { weight of dry matter }\end{array}$ & $1.36 \pm 0.01$ & $1.03 \pm 0.02^{\star}$ & $1.19 \pm 0.01$ & $1.01 \pm 0.01^{\star}$ & $1.13 \pm 0.02$ & $0.90 \pm 0.01^{*}$ \\
\hline $\begin{array}{l}\text { Phosphorus con- } \\
\text { tent, g/kg of dry } \\
\text { matter }\end{array}$ & $7.19 \pm 0.07$ & $6.73 \pm 0.03^{\star}$ & $6.62 \pm 0.06$ & $6.70 \pm 0.04$ & $6.33 \pm 0.05$ & $6.72 \pm 0.03^{\star}$ \\
\hline $\begin{array}{l}\text { Potassium content, } \\
\text { g/kg of dry matter }\end{array}$ & $17.48 \pm 0.4$ & $17.07 \pm 0.16^{\star}$ & $17.39 \pm 0.15$ & $17.42 \pm 0.17$ & $15.59 \pm 0.13$ & $17.31 \pm 0.14^{\star}$ \\
\hline
\end{tabular}

Note: ${ }^{*}-$ the difference is significant at $P \leq 0.05$.

On the other hand, in all variants of the experiment, the concentration of non-protein forms of nitrogen was reduced precisely in skotomorphic plants compared with photomorphic ones. In our opinion, this testifies that gibberellin and retardant have a weaker effect on the processes of hydrolysis of reserve proteins and a stronger effect on the transport of non-protein forms of nitrogen to the seedling tissue.

The dynamics of the content of other elements, phosphorus and potassium, was similar to that observed during the germination of maize seeds: in the control seed sample, there was a decrease in the content of these elements. The use of either preparation did not affect their content or even increased under the conditions of skotomorphogenesis. In our opinion, this testifies that the reserves of phosphorus and potassium under the effects of gibberellin and tebuconazole are used in the processes of morphogenesis in later stages of ontogeny.
Our results show the significant influence of preparations on germination and the intensity of the use of reserve compounds of cotyledons of pumpkin seeds (Table 3 ).

Gibberellin accelerated, and retardant slowed germination. Gibberellic acid and chlormequat chloride changed the intensity of the use of pumpkin seed reserve substances. Under the effect of gibberellic acid at the time of disclosure of cotyledons, the utilization rate was the largest, and for the actions of retardant - the smallest in comparison with control. In seedlings that grew in the dark, it was noted more intensive use of reserve substances of seeds in the process of germination.

The chromatographic analysis of pumpkin oil revealed six higher fatty acids:palmitic, stearic, oleic, linoleic, linolenic and arachinic (Table 4).

It is known that the seed germination of crops containing oil as a reserve substance 
Table 3. Influence of gibberellin and tebuconazole on the germination rates of pumpkin seeds, variety Mozoliivsky 15, under the conditions of photo- and skotomorphogenesis

\begin{tabular}{|c|c|c|c|c|c|c|}
\hline \multirow{2}{*}{ Indicator } & \multicolumn{2}{|c|}{ Control } & \multicolumn{2}{|c|}{ Gibberellin } & \multicolumn{2}{|c|}{ Chlormequatchloride } \\
\hline & Light & Dark & Light & Dark & Light & Dark \\
\hline $\begin{array}{l}\text { Lengthofhypocotyl, } \\
\mathrm{cm}\end{array}$ & $10.4 \pm 0.60$ & $11.8 \pm 0.40^{*}$ & $14.2 \pm 0.50$ & $16.8 \pm 0.30^{\star}$ & $4.7 \pm 0.50$ & $5.93 \pm 0.40^{*}$ \\
\hline $\begin{array}{l}\text { Coefficient of use of } \\
\text { reserve substances, } \%\end{array}$ & $18.3 \pm 0.64$ & $35.9 \pm 0.85^{\star}$ & $22.2 \pm 0.35$ & $38.4 \pm 0.32^{\star}$ & $13.87 \pm 0.56$ & $22.9 \pm 0.18^{\star}$ \\
\hline $\begin{array}{c}\text { Oil content, } \% \text { mass } \\
\text { of dry matter }\end{array}$ & $8.8 \pm 0.20$ & $7.6 \pm 0.10^{*}$ & $12.2 \pm 0.30$ & $11.6 \pm 0.20$ & $22.4 \pm 0.30$ & $22.4 \pm 0.30$ \\
\hline $\begin{array}{c}\text { Total nitrogen con- } \\
\text { tent, } \% \text { mass of dry } \\
\text { matter }\end{array}$ & $6.05 \pm 0.01$ & $6.91 \pm 0.01^{\star}$ & $5.99 \pm 0.02$ & $6.73 \pm 0.03^{\star}$ & $7.13 \pm 0.02$ & $7.16 \pm 0.01^{\star}$ \\
\hline $\begin{array}{l}\text { The content of pro- } \\
\text { tein nitrogen, mass } \\
\text { of dry matter }\end{array}$ & $4.04 \pm 0.01$ & $4.75 \pm 0.01^{\star}$ & $3.68 \pm 0.01$ & $4.76 \pm 0.01^{\star}$ & $4.94 \pm 0.04$ & $5.09 \pm 0.02^{*}$ \\
\hline $\begin{array}{l}\text { Content of non-pro- } \\
\text { tein nitrogen, } \% \text { mass } \\
\text { of dry matter }\end{array}$ & $2.01 \pm 0.04$ & $2.16 \pm 0.05^{\star}$ & $2.31 \pm 0.03$ & $1.97 \pm 0.02^{\star}$ & $2.19 \pm 0.02$ & $2.07 \pm 0.01^{\star}$ \\
\hline
\end{tabular}

Note: ${ }^{\star}$ - the difference is significant at $P \leq 0.05$.

Table 4. The content of higher fatty acids in cotyledon oil of pumpkin seedlings, variety Mozoliivsky 15, under the effect of gibberellic acid and chlormequat chloride under the conditions of photo- and skotomorphogenesis (\%)

\begin{tabular}{|c|c|c|c|c|c|c|}
\hline \multirow{2}{*}{$\begin{array}{l}\text { Higher fatty } \\
\text { acids }\end{array}$} & \multicolumn{3}{|c|}{ Photomorphogenesis } & \multicolumn{3}{|c|}{ Skotomorphogenesis } \\
\hline & GA3 & Control & $\mathrm{CCC}$ & GA 3 & Control & $\mathrm{CCC}$ \\
\hline Palmitic & $10.93 \pm 0.01$ & $10.36 \pm 0.15$ & $11.85 \pm 0.13^{*}$ & $11.46 \pm 0.23^{*}$ & $13.22 \pm 0.12^{\star}$ & $13.68 \pm 0.19$ \\
\hline Stearic & $8.12 \pm 0.02$ & $7.93 \pm 0.01$ & $8.06 \pm 0.16^{\star}$ & $8.06 \pm 0.04^{\star}$ & $5.38 \pm 0.09$ & $5.39 \pm 0.08$ \\
\hline Oleic & $23.75 \pm 0.06$ & $23.94 \pm 0.11$ & $24.59 \pm 0.01^{\star}$ & $24.22 \pm 0.17^{*}$ & $14.08 \pm 0.08$ & $14.89 \pm 0.06^{*}$ \\
\hline Linoleic & $54.00 \pm 0.08^{*}$ & $53.74 \pm 0.05$ & $53.76 \pm 0.32$ & $53.70 \pm 0.07^{\star}$ & $63.04 \pm 0.31$ & $63.83 \pm 0.06^{*}$ \\
\hline Linoleic & $2.74 \pm 0.04^{*}$ & $3.61 \pm 0.005$ & ${ }^{\star} 1.44 \pm 0.02$ & $2.04 \pm 0.02^{*}$ & $4.03 \pm 0.03$ & $2.1 \pm 0.11^{\star}$ \\
\hline Arachic & $0.45 \pm 0.005$ & $0.42 \pm 0.025$ & ${ }^{\star} 0.30 \pm 0.005$ & $0.52 \pm 0.005^{\star}$ & $0.25 \pm 0.005$ & $0.11 \pm 0.005^{\star}$ \\
\hline $\begin{array}{c}\text { Content of } \\
\text { saturated } \\
\text { HFA }\end{array}$ & $19.5 \pm 0.03^{\star}$ & $18.71 \pm 0.19$ & $\star 20.21 \pm 0.29$ & $20.04 \pm 0.28^{*}$ & $18.85 \pm 0.22$ & $19.18 \pm 0.27$ \\
\hline $\begin{array}{c}\text { Content of } \\
\text { unsaturated } \\
\text { HFA }\end{array}$ & $80.49 \pm 0.18^{\star}$ & $81.29 \pm 0.17$ & $\star 79.79 \pm 0.35$ & $79.96 \pm 0.26^{*}$ & $81.15 \pm 0.42$ & $80.82 \pm 0.23$ \\
\hline $\begin{array}{l}\text { Ratio unsatu- } \\
\text { rated/satu- } \\
\text { rated HFA }\end{array}$ & 4.10 & 4.30 & 3.95 & 3.99 & 4.30 & 4.20 \\
\hline
\end{tabular}

Notes: 12 th day of germination; ${ }^{\star}-$ the difference is significant at $P \leq 0.05$. 
is accompanied by a decrease in the ratio of unsaturated/saturated higher fatty acids as a result of the saturation processes. We have not established a clear relationship between the use of preparation and the indicated ratio in the process of germination of seeds, which, in our opinion, indicates the absence of influence of gibberellins on the activity of saturases (Table 4).

The results of the analysis of the oil content in cotyledons according to the experimental variants (Table 3 ) indicate that under the effect of gibberellin, the content of this substance remained higher at the end of the germination period compared with the control. In this case, the coefficient of use of seeds substances in this variant was the highest. In our opinion, this testifies that increased growth under the effect of phytohormon is determined not only by the rapid utilization of lipids, but also by possible increased hydrolysis of other reserve substances of cotyledons - nitrogencontaining compounds.

The analysis of our data shows that under the conditions of photo- and skotomorphogenesis, there was a significant outflow of nitrogen from cotyledons into sprouts, and the content of total and protein nitrogen in the non-fatty material of cotyledon leaves significantly differed: in particular, it was lower in the variant of development of seedlings on light. Obviously, this indicates a more intensive use of cotyledon protein for growth processes in the formation of seedlings structures under photomorphogenesis conditions.

The different rate of the growth processes under the action of retardant and gibberellin was accompanied by different intensity of outflow of nitrogen-containing compounds from cotyledons. In particular, in the light, the smallest content of protein nitrogen remained in the variant with gibberellin, and the largest content in the variant with the use of its antagonist, chlormequat chloride. When germinating in the dark, protein nitrogen was least intensively used under the action of retardant. In the control and in the variant with the use of gibberellin, the intensity of the use of protein nitrogen was the same; however, the decrease in the total nitrogen content in cotyledons under the influence of phytohormones was more intensive due to non-protein fraction.

Plant growth under the conditions of photo- and skotomorphogenesis in the heterotrophic phase of development is accompanied by a change in the nature of the donor-acceptor relationship, since, under the action of light, the rates of development of seedlings and organogenesis differ significantly (Kutschera, Briggs, 2013; Wu, 2014). On the other hand, the important role of gibberellins in stimulating of seed germination is known well. It is determined by the ability of phytohormones to stimulate the release of $\alpha$-amylase into the endosperm by the embryo, leading to the splitting of starch grains (Rademacher, 2016). Today, it has been established that light can modify the growth and morphogenesis of plants through the restructuring of the hormonal complex (Nakaminami et al., 2003; De Wit, Pierik, 2016).

The combined use of light, gibberellins, and retardants for artificial regulation of the tension of the donor-acceptor relations in a plant can become an effective method for studying the role of phytohormones and finding out the features of the use of plant reserve compounds in experimental studies into germination processes. The obtained results indicate that under the effect of gibberellins, a more intensive stimulation of the growth of the aboveground part and root system of seedlings of plants that contain different types of reserve substances - starch (maize), proteins (beans) and oils (pumpkin) as compared to control was observed. The morphological changes of seedlings in the variants of the experiment were determined by different degrees of the use of the reserve substances of the seed during the period of germination - the coefficient of the use of reserve substances was maximal under the action of gibberellin, and was minimal under the action of retardants (tebuconazole, chlormequat chloride) both in the light and in the dark. 
The change in the growth characteristics and the coefficient of the use of reserve substances of beans seeds was accompanied by a decrease in the content of total nitrogen, indicating the use of reserve nitrogen-containing compounds in the processes of morphogenesis. In this case, under the conditions of skotomorphogenesis, the content of protein nitrogen in the control was lower than in the photomorphic seedlings, and the opposite relation was noted for the actions of gibberellin and retardant. On the other hand, in all variants of the experiment, the concentration of non-protein forms of nitrogen was reduced precisely in skotomorphic plants compared with photomorphic ones. In our opinion, this indicates that gibberellin and retardant have a weaker effect on the processes of hydrolysis of reserve proteins, and a stronger effect on the transport of non-protein forms of nitrogen to the tissue of the sprout. The process of germination of pumpkin seeds was characterized by the intensive use of oil.

However, the growth of seedlings under the action of gibberellin was not accompanied by more intensive use of oil: its content in this variant was higher than in the control. In our opinion, this indicates that under the effects of phytohormon, increased growth is determined not only by the rapid utilization of lipids, but also by possible increased hydrolysis of other reserve substances of cotyledons - nitrogencontaining compounds. A significant outflow of nitrogen from cotyledons into sprouts occurred under the conditions of photo- and skotomorphogenesis, and the content of total and protein nitrogen in the defatted material of the cotyledonary leaves significantly differed. In particular, it was smaller in the development of seedlings in the light. This points to the more intensive use of cotyledon protein in growth processes in the formation of seedling structures under photomorphogenesis conditions. A different rate of growth processes under the action of retardant and gibberellin was accompanied by a different intensity of the outflow of nitrogen-containing compounds from cotyledons. In particular, in the light, the lowest protein nitrogen remained in the variant with gibberel- lin, and highest in the variant with the use of its antagonist - chlormequat chloride. When germinating in the dark, protein nitrogen was used the least intensively under the action of retardant. In the control and in the variant with gibberellin, the intensity of the use of protein nitrogen was the same; however, the decrease in the total nitrogen content in cotyledons under the influence of phytohormones occurred more intensively due to the non-protein fraction. Consequently, the growth stimulating effect of gibberellin significantly increased under the conditions of skotomorphogenesis, and light blocked the growth-stimulating effect of phytohormones. The antigibberellin effect of tebuconazole resulted in significant inhibition of germination and the use of reserve compounds of the seeds, both in the light and in the dark.

\section{CONCLUSIONS}

Combined use of light, gibberellins, and retardants for artificial regulation of the tension of donor- acceptor relations in a plant can become an effective method for studying the role of phytohormones and finding out the features of the use of plant reserve compounds in experimental studies into germination processes. Under the effect of gibberellins, the growth of the above-ground part and the root system of seedlings of plants containing different types of reserve substances - starch (maize), proteins (beans) and oils (pumpkin) - is more intense in comparison with the control. The process was faster in the dark. The use of antigibberellin preparation of tebuconazole substantially blocked the process of germination under the conditions of photomorphogenesis and skotomorphogenesis. The morphological changes of seedlings in the variants of experiment were determined by different degrees of the use of seed reserve substances during the period of germination: the coefficient of the use of reserve substances was maximal under the effect of gibberellin, and was minimal under the action of retardants (tebuconazole, chlormequat chloride) both in the light and in the dark. This points to the universal role of 
gibberellin in seed germination processes, regardless of the type of the reserve substance.

Received 24 June 2019

Accepted 7 November 2019

\section{References}

1. Altintas S. Effects of chlormequat chloride and different rates of prohexadione-calcium on seedling growth, flowering, fruit development and yield of tomato. Afr J Biotechnol. 2011; 10(75): 17160-9.

2. AOAC. Official methods of analysis of association of analytical chemist international 18th ed. Rev. 3.2010. Asso of Analytical Chemist. Gaithersburg, Maryland, USA, 2010.

3. Bonelli LE, Monzon JP, Cerrudo A, Rizzalli RH, Andrade FH. Maize grain yield components and source-sink relationship as affected by the delay in sowing date. Field Crops Res. 2016; 198: 215-25.

4. Carvalho MEA, Castro CPR, Castro FMV, Mendes ACC. Are plant growth retardants a strategy to decrease lodging and increase yield of sunflower. Comun Sci. 2016; 7(1): 154-64.

5. De Wit M, Pierik R. Photomorphogenesis and Photoreceptors. Canopy Photosynthesis: From Basics to Applications. 2016; 42: 171-86.

6. Folta KM, Pontin MA, Karlin-Neumann G. Genomic and physiological studies of early cryptochrome 1 action demonstrate roles for auxin and gibberellin in the control of hypocotyl growth by blue light. Plant J. 2003; 36(2): 203-14.

7. Franklin KA. Photomorphogenesis: plants feel blue in the shade. Curr Biol. 2016; 26(24): 1275-6.

8. Hedden P, Thomas SG. Annual Plant Reviews. Vol. 49. The Gibberellins. John Wiley \& Sons; 2016. $472 \mathrm{p}$.

9. Hornitschek P, Kohnen MV, Lorrain S, Rougemont J, Ljung K, López-Vidriero I, Franco-Zorrilla JM, Solano R, Trevisan M,
Pradervand S, Xenarios I, Fankhauser C. Phytochrome interacting factors 4 and 5 control seedling growth in changing light conditions by directly controlling auxin signaling. Plant J. 2012; 71(5): 699-711.

10. Humplík JF, Turečková V, Fellner M, Bergougnoux V. Spatio-temporal changes in endogenous abscisic acid contents during etiolated growth and photomorphogenesis in tomato seedlings. Plant Signal Behav. 2015; 10(8): e1039213.

11. Koutroubas SD, Damalas CA. Morpho-physiological responses of sunflower to foliar applications of chlormequat chloride (CCC). Biosci J. 2016; 32(6): 1493-501.

12. Kuryata VG. Retardanty - modyfikatory gormonalnogo status roslyn. Fiziologija roslyn: problemy ta perspektyvy rozvytku. T. 1. Logos, Kyiv, 2009. Ukrainian.

13. Kuryata VG, Golunova LA. Peculiarities of the formation and functioning of soybeanrhizobial complexes and the productivity of soybean culture under the influence of retardant of paclobutrazol. Ukr J Ecol. 2018; 8(3): 98-105.

14. Kuryata VG, Khodanitska OO. Features of anatomical structure, formation and functioning of leaf apparatus and productivity of linseed under chlormequat chloride treatment. Ukr J Ecol. 2018; 8(1): 918-26.

15. Kuryata VG, Kravets OO. Features of morphogenesis, accumulation and redistribution of assimilate and nitrogen containing compounds in tomatoes under retardants treatment. Ukr J Ecol. 2018; 8(1): 356-62.

16. Kuryata VG, Polyvanyi SV. Formation and functioning of source-sink relation system of oil poppy plants under treptolem treatment towards crop productivity. Ukr J Ecol. 2018; 8(1): 11-20.

17. Kuryata VG, Poprotska IV, Rogach TI. The impact of growth stimulators and retardants on the utilization of reserve lipids by sunflower seedlings. Regul Mech Biosyst. 2017; 8(3): $317-22$. 
18. Kutschera U, Briggs WR. Seedling development in buckwheat and the discovery of the photomorphogenic shade-avoidance response. Plant Biol (Stuttg). 2003; 15(6): 931-40.

19. Matysiak K, Kaczmarek S. Effect of chlorocholine chloride and triazoles - tebuconazole and flusilazole on winter oilseed rape (Brassica napus var. Oleifera L.) in response to the application term and sowing density. J Plant Prot Res. 2013; 53(1): 79-88.

20. Nakaminami K, Sawada Y, Suzuki M, Kenmoku H, Kawaide H, Mitsuhashi W, Sassa T, Inoue Y, Kamiya Y, Toyomasu T. Deactivation of gibberellin by 2-oxidation during germination of photoblastic lettuce seeds. Biosci Biotechnol Biochem. 2003; 67(7): 1551-8.

21. Rademacher W. Chemical regulators of gibberellin status and their application in plant production. Annu Plant Rev. 2016; 49: 359-403.

22. Ramburan S, Greenfield PL. Use of ethephon and chlormequat chloride to manage plant height and lodging of irrigatend barley (cv. Puma) when hight rates of $\mathrm{N}$-fertiliser are applied. S Afr J PlantSoil. 2007; 24(4): 181-7.

23. Sang-Kuk K, Hak-Yoon K. Effects of gibberellin biosynthetic inhibitors on oil, secoisolaresonol diglucoside, seed yield and endogenous gibberellin content in flax. Korean J Plant Res. 2014; 27(3): 229-35.

24. Savage JA, Haines DF, Holbrook NM. The making of giant pumpkins: how selective breeding changed the phloem of Cucurbita maxima from source to sink. Plant Cell Environ. 2015; 38(8): 1543-54.

25. Sugiura D, Sawakami K, Kojim M, Sakakibara H, Terashima I, Tateno M. Roles of gibberellins and cytokinins in regulation of morphological and physiological traits in Polygonumcuspidatum responding to light and nitrogen availabilities. Funct Plant Biol. 2015; 42(4): 397.

26. Wang Y, Gu W, Xie T, Li L, Sun Y, Zhang H, Li J, Wei S. Mixed compound of DCPTA and
CCC increases maize yield by improving plant morphology and upregulating photosynthetic capacity and antioxidants. PLOS ONE. 2016; 11(2): e0149404.

27. $\mathrm{Wu} \mathrm{SH}$. Gene expression regulation in photomorphogenesis from the perspective of the central dogma. Annu Rev Plant Biol. 2014; 65: 311-33.

28. Yan Y, Wan Y, Liu W, Wang X, Yong T, Yang W. Influence of seed treatment with uniconazole powder on soybean growth, photosynthesis, dry matter accumulation after flowering and yield in relay strip intercropping system. Plant Prod Sci. 2015; 18(3): 295-301.

29. Yang L, Yang D, Yan X, Cui L, Wang Z, Yuan H. The role of gibberellins in improving the resistance of tebuconazole-coated maize seeds to chilling stress by microencapsulation. Sci Rep. 2016; 60: 1-12.

30. Yu SM, Lo ShF, Ho TD. Source-Sink Communication: Regulated by Hormone, Nutrient, and Stress Cross-Signaling. Trends Plant Sci. 2015; 20(12): 844-57.

\section{Iryna Poprotska, Volodymyr Kuryata, Olena Khodanitska, Stepan Polyvanyi, Lyudmyla Golunova, Yuriy Prysedsky \\ GIBERELINŲ IR RETARDANTŲ POVEIKIS SĖKLŲ DAIGUMUI SKOTOMORFOGENEZĖS IR FOTOMORFOGENEZĖS SĄLYGOMIS}

\section{Santrauka}

Buvo tiriamas fitohormono giberelino ir retardantų - tebukonazolo ir chlormekvato chlorido - poveikis augalų sèklų daigumui šviesoje (fotomorfogenezè) ir tamsoje (skotomorfogenezè). Nustatyta, kad giberelinas intensyviau stimuliuoja kukurūzų, pupelių ir moliūgų sodinukų antžeminę dalị ir šaknų sistemą, palyginti su kontrole. Procesas greičiau vyko tamsoje. Tebukonazolo ir chlormekvato chlorido naudojimas reikšmingai slopino daigumą tiek šviesoje, tiek tamsoje. Augalų rezervinių medžiagu naudojimo koeficientas veikiant giberelinui buvo 
maksimalus, o veikiant retardantams - minimalus tiek skotomorfogenezès, tiek fotomorfogenezès sąlygomis. Greta pupelių sèklų augimo charakteristikų ir rezervinių medžiagų naudojimo koeficiento pokyčių pastebètas sumažejęs bendrojo azoto kiekis rodo rezervinio azoto turinčių junginių naudojimą morfogenezès procesuose. Kontrolinèje grupejje azoto kiekis skotomorfogenezès sąlygomis buvo mažesnis nei fotomorfinių daigų, o giberelino ir retardanto poveikis buvo priešingas. Vèlesniuose daiginimo etapuose didžiausias moliūgų sèklų aliejaus kiekis išliko dyglialapiuose fotomorfinių augalų lapuose veikiant chlormekvato chloridui, ir tai aiškiai koreliavo su mažiausiu intensyviu sodinukų augimo greičiu tiek šviesoje, tiek tamsoje. Skotomorfogenezès sąlygomis giberelino savybė stimuliuoti augimą labai sustiprèjo, o šviesa blokavo šio fitohormono veikimą.

Raktažodžiai: šviesos poveikis, morfogenezè, „source-sink“ sistema, sèklų daigumas, giberelinai, retardantai 